\title{
Boost, Control, or Both of Korean Housing Market: 831 Countermeasures
}

\author{
Moonseo Park, M.ASCE${ }^{1}$; Man-hyung Lee ${ }^{2}$; Hyun-soo Lee, M.ASCE ${ }^{3}$; and Sungjoo Hwang ${ }^{4}$
}

\begin{abstract}
Although the Korean government reported a housing supply ratio of more than $100 \%$ in the early 2000 s, regional and class disparities in the Korean housing sector have not been correspondingly alleviated. Unfortunately, many Korean households are still enduring the economic burden caused by cyclical price variation, while many housing construction companies are on the verge of bankruptcy. To resolve the ever-expanding socioeconomic problems in the housing and real estate sector, the current Korean government proposed 831 Countermeasures, which has since met with much controversy. In an effort to address these issues, this paper utilizes a qualitative system dynamics model to elucidate and interrogate complex Korean housing mechanisms. By mapping bibliographical and experimental knowledge with causal loop diagrams, the positive and adverse effects of the 831 Countermeasures are also analyzed. Finally, based on the research findings, alternative policy guidelines are proposed that can be used to strengthen positive housing structures and obviate negative ones.
\end{abstract}

DOI: 10.1061/(ASCE)CO.1943-7862.0000159

CE Database subject headings: Korea, south; Housing; Policies.

Author keywords: 831 Countermeasures; Korean housing market; Policies.

\section{Introduction}

The Korean War (1950-1953) not only devastated Korea's territories, but also resulted in an extreme shortage of urban infrastructure, not to mention housing. Since the war, the Korean government has adopted diverse urban policies in order to accommodate huge in-migration toward the capital region, especially Seoul. Nevertheless, such policies have also exacerbated urban problems. Furthermore, over the last four to five decades, unprecedented economic growth has fundamentally changed Korea's housing industry. Under such circumstances, the so-called "speculative group" has dared to pursue windfall incomes from the housing and real-estate sector. Ultimately, all of these factors have contributed to the aggravation of a wide range of social problems.

There are several reasons that home ownership is a key and

${ }^{1}$ Associate Professor, Dept. of Architecture, Seoul National Univ., San 56-1 Shinrim-dong, Seoul, 151-742, Korea (corresponding author). E-mail: mspark@snu.ac.kr

${ }^{2}$ Professor, Dept. of Urban Engineering, Chungbuk National Univ., 410 Seongbong-ro, Cheongju, Chungbuk, 361-763, Korea. E-mail: manlee@ chungbuk.ac.kr

${ }^{3}$ Professor, Dept. of Architecture, Seoul National Univ., San 56-1 Shinrim-dong, Seoul, 151-742, Korea. E-mail: hyunslee@ snu.ac.kr

${ }^{4}$ MS Student, Dept. of Architecture, Seoul National Univ., San 56-1 Shinrim-dong, Seoul, 151-742, Korea. E-mail: nkkt14@snu.ac.kr

Note. This manuscript was submitted on September 16, 2008; approved on October 5, 2009; published online on October 6, 2009. Discussion period open until November 1, 2010; separate discussions must be submitted for individual papers. This paper is part of the Journal of Construction Engineering and Management, Vol. 136, No. 6, June 1, 2010. CASCE, ISSN 0733-9364/2010/6-693-701/\$25.00. safe form of property investment. However, in Korea, because increases in house prices have far surpassed increases in income, imputed and even effective demand have been easily converted into speculative demand. Therefore, it is almost inevitable that house price bubbles have become ubiquitous in the Korean housing market. Also, the Korean government's direct and indirect involvement and interference in the housing market have often caused a series of negative effects.

Indeed, even though the Korean government recorded a housing supply ratio of more than $100 \%$ in the early 2000 s, this figure does not correlate with a decrease in regional and class disparities in the Korean housing sector. In fact, cyclical price variation continues to negatively impact many Korean households, while many housing construction companies are nearing bankruptcy. To cope with these increasing socioeconomic problems, the current Korean government announced a comprehensive real-estate program-dubbed "831 Countermeasures"-on August 31, 2005. However, this initiative-based program has incited a barrage of arguments in favor of, and against, its proposals. Notably, most of these arguments are predominantly based on subjective reasoning and anecdotal evidence.

This paper, on the other hand, examines the impact of the 831 Countermeasures through a qualitative lens by applying an existing theory of comprehensive housing dynamics to Korea's diverse housing mechanisms. Then, by mapping pertinent bibliographical and experimental knowledge with causal loop diagrams, this research develops a Korean housing market dynamics model. This model is based on universal housing market models; however, it is also constructed to reflect the specific characteristics of Korea's housing supply. Through this approach, the positive and adverse effects of the 831 Countermeasures are analyzed. Finally, based on the research findings, alternative policy guidelines are outlined 
that could be used to enhance positive structures, while obviating negative ones.

\section{Previous Research}

\section{Literature Review}

Several studies have been conducted on housing price determinants and housing price models. Englund et al. (1999) provided a unique methodology for computing housing price indexes in an attempt to understand the effect of temporal aggregation upon estimates of housing prices and their volatilities. Guirguis et al. (2005) employed alternative estimation methodologies in which the parameters are allowed to vary over time in order to predict housing prices. Using quantile regression, Zietz et al. (2008) suggested determinants of house prices that contribute to observed variations in the estimated prices of housing characteristics. However, only a few influenced factors were considered in these studies. Moreover, it is difficult to apply housing policies to the price models.

Also, there are a handful of studies that examine housing market and housing policy analysis. Kim (2004) explored the nexus between housing and the Korean economy, focusing on house price, inflation, housing investment, and government intervention. Cho and Ma (2006) identified the long-term relationship between housing values and interest rates in the Korean housing market using the cointegration test and spectral analysis. As well, Park et al. (2008) demonstrated the effectiveness of bank lending restrictions and analyzed the relationship between bank lending and apartment prices using real data. However, these studies conducted their analysis using empirical approaches with only a few factors, instead of considering diverse perspectives.

\section{System Dynamics Modeling}

System Dynamics (SD) is a modeling tool that provides an understanding of strategic problems in complex dynamic systems. An SD model provides system users with insight into the feedback processes and dynamic behavior of a system. This model is made up of feedback loops and their variables, which are known as causal loop diagrams or influence diagrams. Feedback loops can be divided into two categories: (1) a balancing loop which is a goal seeking structure of the system that causes balance and stability and (2) a reinforcing loop which generates a growth process in which action builds a result that generates still greater action (Ahmad and Simonovic 2000). System dynamics modeling is used in this study because it enables a comprehensive solution and systematic approach to analyze the impact of housing policies.

\section{Real Estate Policies and 831 Countermeasures}

\section{Korean Real Estate Policies}

From the early 1960s to the late 1990s, real-estate prices cyclically skyrocketed as Korea experienced rapid urbanization and industrialization. In the late 1990s in particular, price increases in the real estate sector related to land, housing, and Chonsei (in Korean, "Chonsei" refers to the lease of a house or room on a deposit basis; that is, a lessee can rent a house or room with a large deposit) were astonishing. Consequently, in late 1997, the
Korean government was forced to adopt boosting policies in order to escape from the so-called "foreign currency crisis." More recently, as both effective and speculative demand have comingled in the marketplace, housing problems have become even more complicated. While the Korean government has often depended on the "invisible hand" (as delineated by Adam Smith), more recently, to cope with this aggravated situation, the Korean government has not hesitated to expand the reach of its housing policies.

Nonetheless, most of these government-initiated real-estate or housing policies have come under heavy attack, and have often been criticized as being superficial and merely palliative because they generally have a lesser impact and shorter duration than market-driven initiatives. In particular, opponents of governmentinitiated housing policies have argued that although the spillover effects of antispeculation policies usually disappear within 2-3 years, the unforeseen negative effects, which can arise over the same period, can become rampant if unchecked. Indeed, when the Korean government implemented a series of housing policies from the mid-1980s to the mid-1990s, adequate attention was not given to the potential adverse effects of these policies.

Unfortunately, government mismanagement of this sort has become a trend. For example, from 1997 to 2000, approximately 10 types of housing policies were implemented as economy-boosting measures. In contrast, from 2002 to 2003, the Korean government prepared 13 countermeasures and 16 actions targeted solely against antispeculation policies (Kim and Lee 2005). Stridently opposing speculation, the government has performed tax investigations, crackdowns, and transaction moratoria. In light of the acute nature of Korea's housing problems, these government measures seem inevitable. However, it must be acknowledged that such intervention has contributed to increased uncertainty in the housing market. Indeed, in retrospect, it can be observed that the government's antispeculation and price normalization policies have not been consistently maintained, sometimes even fueling price increases. For instance, government announcements have not always been congruent with market cycles, as demonstrated by the Korean government's tendency to hastily publicize antispeculation measures which are swiftly followed by the proposal of economy-boosting measures.

\section{Countermeasures}

On August 31, 2005, the Korean government announced a set of comprehensive real-estate programs called 831 Countermeasures. These government initiatives were founded on the assumption that former housing policies are overly skewed toward supply or demand and therefore are only useful in the short term. These initiatives propose to maintain economic balance by: (1) increasing tax bases for real-estate purchases, capital gains, and transactions; (2) discouraging speculative demand; and (3) expanding the supply of public residential lots and apartment complexes. As shown in Table 1, the 831 Countermeasures are specifically aimed at maintaining middle class residential stability, enhancing transparency in real-estate transactions, controlling speculative demand, and expanding both housing stocks and residential lots.

\section{Policy Model Development}

Here, the status quo of the Korean housing market and the procon debates circling the 831 Countermeasures are explained and represented by a series of causal loops. For these purposes, it is 
Table 1. Legends in the Causal Loop Diagrams

\begin{tabular}{|c|c|c|}
\hline Legends & & Explanation \\
\hline $\mathrm{A} \stackrel{+}{\longrightarrow} \mathrm{B}$ & \multirow{2}{*}{$\begin{array}{l}\text { When other conditions } \\
\text { are the same }\end{array}$} & $\begin{array}{c}\text { When Factor A increases (decreases), Factor B } \\
\text { increases (decreases) }\end{array}$ \\
\hline $\mathrm{A} \longrightarrow \mathrm{B}$ & & $\begin{array}{c}\text { When Factor A increases (decreases), Factor B } \\
\text { decreases (increases) }\end{array}$ \\
\hline
\end{tabular}

\begin{tabular}{c|c}
\hline & Including weighted delayed time between two factors \\
\hline Stock & Positive feedback or self-reinforcing loop \\
\hline & $\begin{array}{r}\text { Negative feedback or self-balancing loop } \\
\hline\end{array}$ \\
\hline
\end{tabular}

assumed that the housing market is composed of the dynamic interaction between three key components: housing supply, demand, and price. This is not only a generally accepted concept in the Korean housing market, but also in the international economy (see Fig. 1).

Fig. 2 presents a synthesized causal loop diagram that represents the three key components mentioned above, as well as a series of real-estate policies and the market responses to these policies. In this model, there are several diagrams which include universal economic principles connected with price, supply, and demand. However, to reflect the specific features of the Korean housing market, this figure also identifies several feedback loops related to housing supply in Korea and particularly to selling houses, which can play a key role in elucidating Korea's housing market mechanisms. In-depth analyses of these loops are provided in subsequent sections of the paper.

\section{Price}

As illustrated by Fig. 2, house price is determined by the supply and demand functions. Even though extraordinary circumstances may arise over a short-term period, house prices are ultimately driven by these market principles. While housing supply includes newly built housing and existing housing on sale, Housing Demand is derived from the sum of both actual demand and investment demand. While actual demand refers to housing demand to meet a means of living, investment demand represents the demand for the accumulation of investment properties. The results

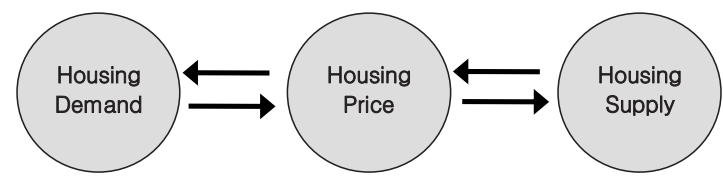

Fig. 1. Basic housing model and its key components of surveys conducted on the determining factors of the housing market support the decision to divide demand into actual demand and investment demand in this research, as $61.1 \%$ of the respondents claimed they would purchase houses with the intent to invest.

Furthermore, overdemand, which is defined as the value derived from subtracting housing supply from housing demand, determines perceived existing house price and the sales rate of newly built housing. While perceived existing house price is transformed into existing house price after the time horizon for existing house price passes, sales rate affects sales unit price of newly built housing via the risk of dead stock. sales unit price is also based on suppliers' expected sales unit price, which is based on production cost (Sterman 2000).

In the Korean housing industry, there is a linking mechanism between newly built housing sales and existing house prices. Indeed, in previous research, it has been verified that if the sales prices of new housing increase, demand will shift to existing

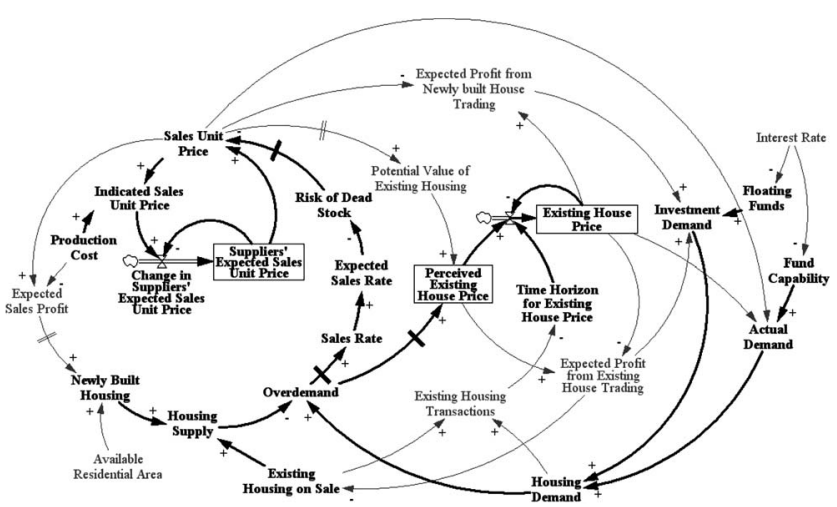

Fig. 2. Causal loop for Korean housing market and house price determinants 


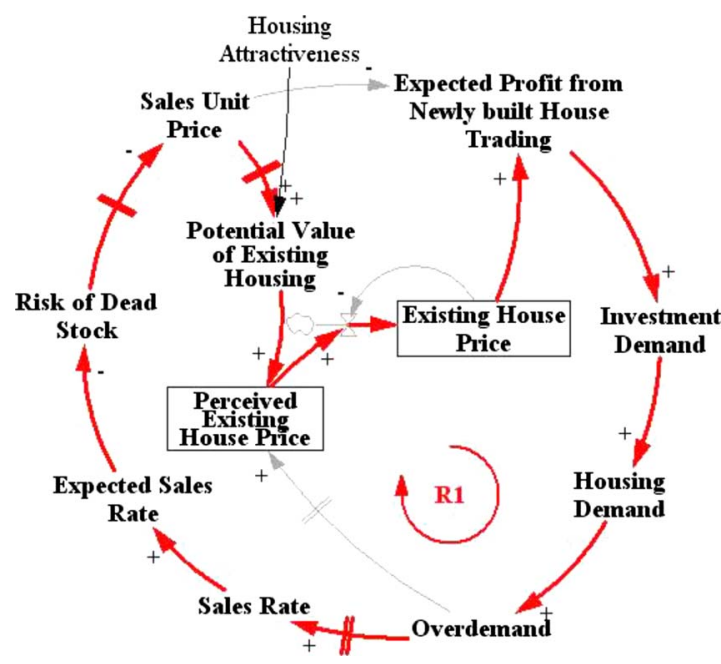

Fig. 3. Linkage mechanism between newly built housing sales and house prices

housing stock as substitute goods, causing a correlative increase in housing prices (Hur and Ha 1990; Hur 1991, 1993). These observations suggest that the sale of newly built housing and the existing housing markets are closely interrelated. This mechanism is analyzed using R1 in Fig. 3. If the sales unit price goes up, this will cause an increase in the potential value of existing housing stocks with similar housing attractiveness. As a direct consequence, the existing house price will be increased via homeowners' perceptions of the value of their houses. If the expected profit from newly built housing trading is achieved, speculative demand (i.e., investment demand) will be incurred. Indeed, the survey results related to future house price volatility demonstrate that $83.3 \%$ of the survey respondents have the expectancy of trading profit production when house prices show an upward tendency. This increased demand will again lead to an increase in sales unit price, therefore forming a set of self-reinforcing loops (R1). In the survey, $91.7 \%$ of the respondents answered that there is a reinforcing connection between existing house prices and sales unit price.

\section{Supply}

The Korean housing supply system is substantially different from that of other countries for several reasons. First of all, the majority of private housing in Korea is under government control, not to mention public housing, which requires direct or indirect public funding. Furthermore, because of policy objectives that prioritize meeting the demand of homeless households, supply is mostly in the form of newly built housing. Lastly, there are minimal differences between the public and private housing supply systems. As a result, the housing market's self-regulating functions do not work properly because of excessive government intervention in the housing supply (Kim and Lee 2005). However, this particular perspective is examined because the legitimacy of the supply market function has become increasingly accepted with the general understanding that policy success, in reality, is heavily dependent on market responses. Therefore, working from within this context, the Korean housing supply mechanism will now be analyzed from a private developer's perspective.

Fig. 4 illustrates the private developer's pricing stratagem. For instance, as seen in this figure, the balancing feedback initiated by sales unit price (B1-a) governs the volume of newly built housing.

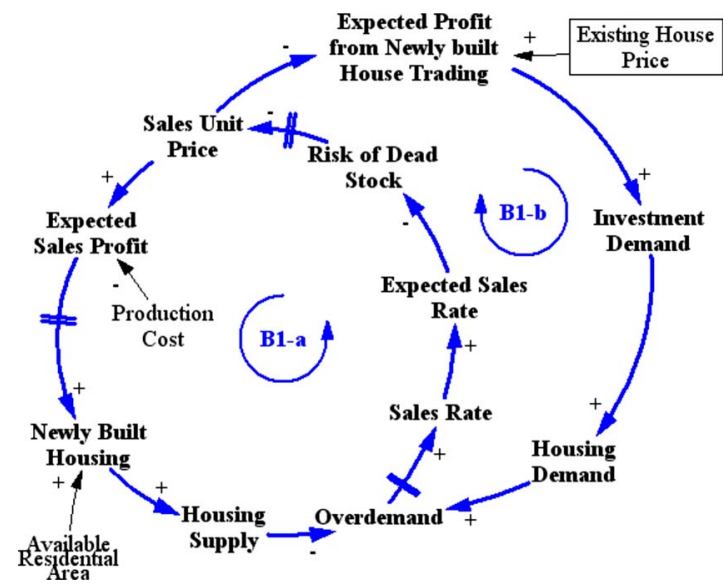

Fig. 4. Newly built housing supply

If sales unit price can be set high with a relatively lower production cost, expected sales profit and, in turn, the volume of newly built housing provided by the private developer, will increase. As a result, once the total housing supply exceeds housing demand, housing sales will be decreased. This reduces the expected sales rate of future housing projects in the area, which consequently forces the private developer to lower sales unit price by increasing the risk of dead stock. This loop effect demonstrates that if a higher expected development profit is expected, the developer can risk increasing sales prices.

Furthermore, there is another balancing feedback initiated by the sales unit price (B1-b). If the sales prices of the developer's new houses are cheaper than the prices of existing houses in the same area, the expected profit from newly built house trading (i.e., the profit gained after selling a newly purchased home, and also the difference between the potential value and actual price of new housing) will increase. This subsequently increases housing demand, fueling consumers' investment demand. Then, developers' expectation of the occupancy rate of their product is increased, and they will set a higher sales unit price accordingly.

The B1-a and B1-b loops represent housing market mechanisms that are generated by a private developer's pricing strategy. These loops indicate how this particular strategy impacts supply volume, demand volume, and sales price. However, when the ceiling price system was introduced into the Korean housing market in 1988, such self-managed mechanisms were severely damaged.

The volume of existing housing on sale, on the other hand, is governed by balancing feedback (B1-c), as shown in Fig. 5. If existing house price in one area is relatively higher than neighboring areas, expected profit from existing housing on sale will be decreased. In this case, apartment owners will be motivated to sell their homes; this will eventually lead to the increase of existing housing on sale. as a consequence, once housing supply exceeds housing demand, perceived existing house price will be decreased, ultimately transforming existing house price.

Existing house price is also governed by another balancing feedback system (B1-d). If existing house price is lower in a particular area than neighboring areas, it is assumed that expected profit from existing house trading will be increased. This increase will, in turn, stimulate investment demand, consequently leading to the increase of housing demand. Then, homeowners will perceive that the value of their homes is greater than their existing prices, and they will accordingly set higher existing house prices. 


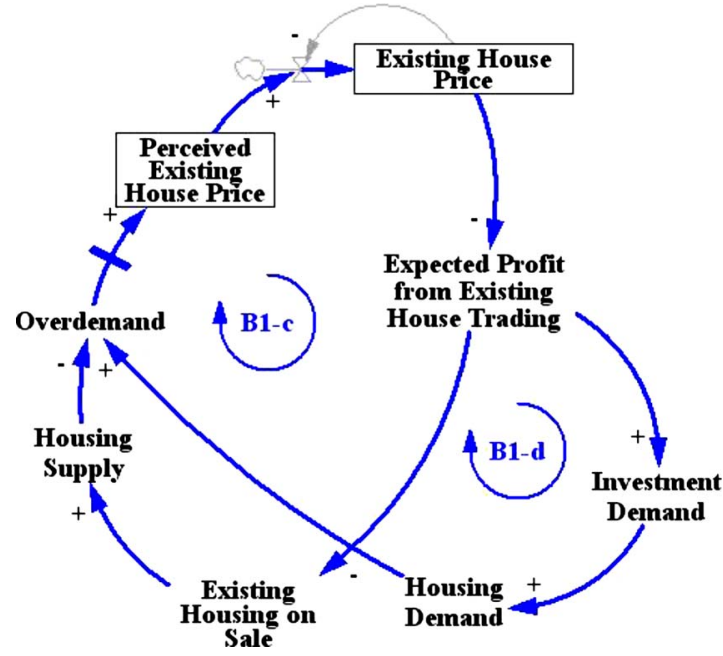

Fig. 5. Existing housing on sale supply

\section{Demand}

According to the theoretical approach of housing demand, increases in purchasing power, urban and total population, and households, are essential in boosting housing demand. To model these dynamics, the size of the homeless population and the purchasing power derived from capital gains are targeted as two additional factors that impact demand besides housing price. As shown in Fig. 6, an increase in sales unit price, existing house price, and homeownership rate will reduce actual demand, which is supported by adequate financial means. On the other hand, decreases in housing demand will eventually lower the sales unit price of newly built housing (along the series of causal links already discussed), activating a self-balancing market mechanism (B2-a). A decrease in housing demand is also transmitted to other areas, decreasing the existing house prices, which again amplifies actual demand (B2-b).

In contrast, as shown in Fig. 7, the expected price difference (i.e., expected profit from newly built house trading) will continue to widen as long as expensive existing housing (i.e., house price) coexists with relatively cheap newly built housing (i.e., sales unit price). This results in a self-reinforcing loop (R2-a). In this case, both house price and investment demand form an ascending curve. In particular, if the sales price is not linked to the price of

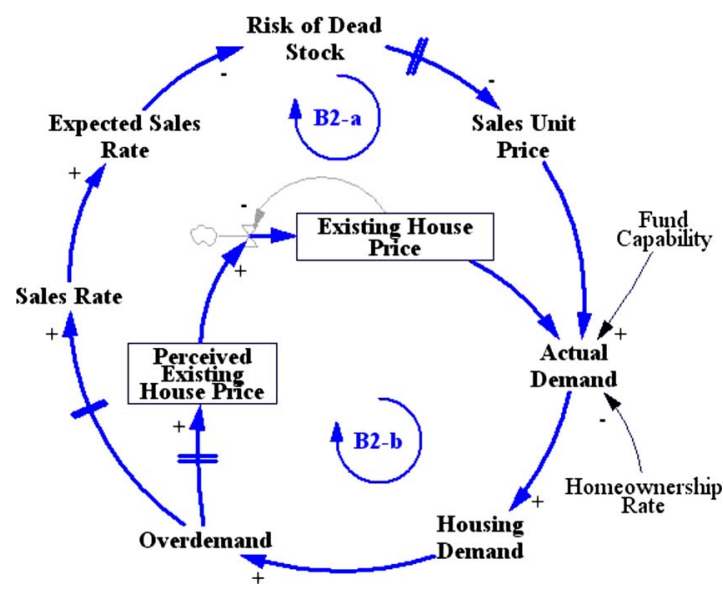

Fig. 6. Actual housing demand

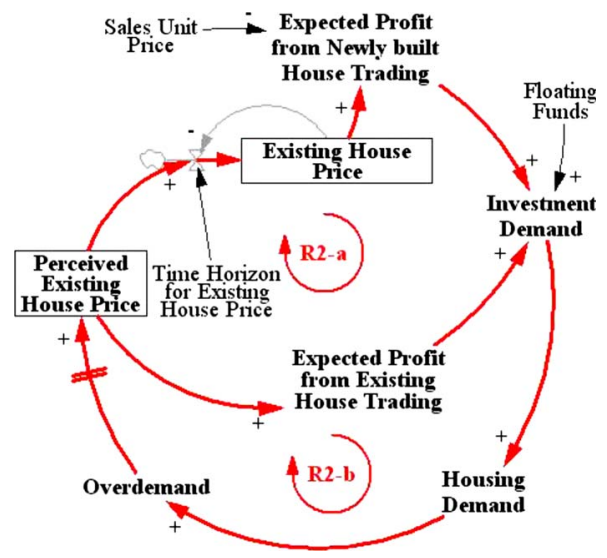

Fig. 7. Investment housing demand

existing housing stocks (e.g., under the ceiling price system), the market power derived from the R2-a loop strengthens over time. However, if the sales price is self-regulated (e.g., if the B1-a loop effect is activated), the expected price difference might be diminished as suppliers increase sales unit price; this will reduce speculative demand and ultimately weaken market power along the same R1-a loop path.

There is also a self-reinforcing loop associated with the investment demand for existing housing. If perceived existing house price increases because of overdemand, a time gap (i.e., time horizon for existing house price) is required before this increase is reflected in actual existing housing price. This time gap creates expected profit from existing house trading, which consequently leads to the amplification of both investment demand and housing demand. When perceived existing house price is not reflected in existing house price (i.e., long time horizon for existing house price), investment demand increases because it is generated by expected profit from existing housing trading. However, as existing house price only fully reflects perceived existing house price after a time horizon has passed, an increase in existing house price will decrease the expected transaction interest, which is a self-regulated market function (B1-d).

\section{Policy Analysis}

So far, with a particular focus on housing supply, demand, and price, the basic structure of the Korean housing market has been interrogated and the dynamic feedback loops associated with this particular market, and how they function, have been illustrated. Based on the results of this analysis, Korea's current housing policies-specifically the 831 Countermeasures and the debates surrounding it-will now be examined focusing on the capital region, which has maintained the normal housing demand with a high level of housing attractiveness. Through a case study, this research analyzes the effects of the 831 Countermeasures' details on a case by case basis. Then, the compound effects of the government policies are illustrated by the behaviors of related causal loops. Fig. 8 presents a diagrammatical expression of the key points and mechanisms of each policy of the 831 Countermeasures, while Table 2 provides the details of each countermeasure. This paper focuses on the Cost-sale price linkage system, New town development, and Tax increases, which are major factors of the 831 Countermeasures. 


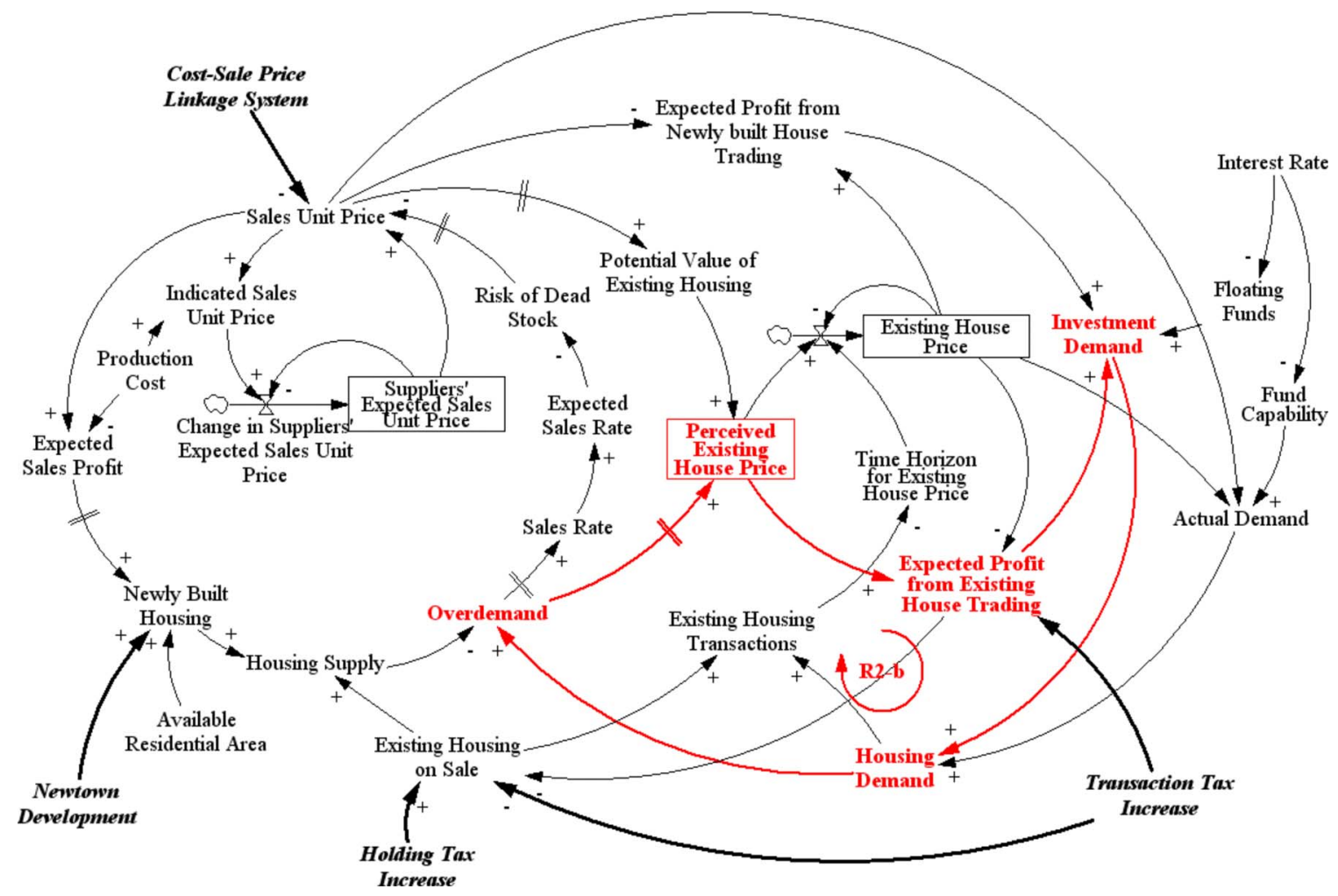

Fig. 8. 831 Countermeasures applied to the Korean housing market and Kangnam

\section{Cost-Sale Price Linkage System}

Applied from 1989 to 1998 , the cost linkage system was based on the popular belief that the unconditional liberalization of sales prices will increase house prices (Kim and Kim 1998). The 831 Countermeasures' readoption of the cost linkage system can be understood as based on a similar notion, and this decision emphasizes the Korean government's prevailing enthusiasm for supplying low-income citizens (who otherwise would be without housing) with small-sized apartments at relatively cheap prices. Nevertheless, after a reconsideration of the policy model seen in

Table 2. Main Contents of the 831 Countermeasures

\begin{tabular}{|c|c|c|c|c|}
\hline \multirow{2}{*}{$\frac{\text { Division }}{\text { House }}$} & & \multicolumn{2}{|r|}{ Main contents } & \multirow{2}{*}{$\begin{array}{c}\begin{array}{c}\text { Application } \\
\text { time }\end{array} \\
2006.01\end{array}$} \\
\hline & Transparency & \multirow{2}{*}{\multicolumn{2}{|c|}{$\begin{array}{l}\text { Report duty of real transaction price } \\
\text { Lower the boom on mediation traders and speculators }\end{array}$}} & \\
\hline & of transaction & & & Ordinary \\
\hline & House supply & \multicolumn{2}{|c|}{ Mini new city (new administrative town) } & 2006 \\
\hline & & \multicolumn{2}{|c|}{ New town development } & 2006 \\
\hline & Public sector role & \multicolumn{2}{|c|}{ Develop public sector (Include new city of Pan-Gyo) } & 2006 \\
\hline & & \multicolumn{2}{|c|}{ Enforcement of bond bidding system and basic cost linkage system } & 2006 \\
\hline & & \multicolumn{2}{|c|}{ Period extension of the resale limitation $(5 \rightarrow 10$ years $)$} & 2006 \\
\hline & Residing stability & \multicolumn{2}{|c|}{ Incentive system of tax and floor area ratio } & 2006 \\
\hline & & \multicolumn{2}{|c|}{ Support of loan for persons purchasing first house } & 2005.10 \\
\hline \multirow[t]{7}{*}{ Tax } & Holding & \multirow{2}{*}{$\begin{array}{l}\text { Comprehensive } \\
\text { real-estate } \\
\text { holding tax }\end{array}$} & Unitary tax as per household & 2006 \\
\hline & & & $\begin{array}{l}\text { Control of the taxation standard (house: } 900 \text { million } \\
\rightarrow 600 \text { million, vacant lot: } 600 \text { million } \rightarrow 300 \text { million) }\end{array}$ & 2006 \\
\hline & & \multirow[t]{2}{*}{ Holding tax } & Abrogation of the supremum of tax & 2006 \\
\hline & & & Rise of the effective tax rates ( $1 \%$ by 2009$)$ & 2006-2009 \\
\hline & \multirow[t]{3}{*}{ Transfer } & \multirow{3}{*}{$\begin{array}{l}\text { Capital gain tax } \\
\text { (transfer tax) }\end{array}$} & Imposition of taxes of real transaction price & 2007 \\
\hline & & & $\begin{array}{l}\text { More levy tax to those possessing } 2 \text { houses per household } \\
(50-60 \%)\end{array}$ & 2006 \\
\hline & & & $\begin{array}{l}\text { More levy tax to those possessing } 3 \text { houses per household } \\
(70 \%)\end{array}$ & 2006 \\
\hline
\end{tabular}

Note: Source: Ministry of Finance and Economy (MOFE), August 31, 2005. 
Table 3. Details and Policy Mechanisms of Each 831 Countermeasure

\begin{tabular}{|c|c|c|}
\hline Description & Details & Policy mechanism in Fig. 10 \\
\hline \multirow[t]{4}{*}{$\begin{array}{l}\text { Cost-sale price } \\
\text { linkage system }\end{array}$} & $\begin{array}{l}\text { - Application of cost-sale price linkage system, } \\
\text { which was applied only if less than } 25.7 \text { pyeong, } \\
\text { to every house in the residential areas provided } \\
\text { by the government }\end{array}$ & $\begin{array}{l}\text { - Cost-sale price linkage system } \rightarrow \text { sales unit price } \\
\text { decrease } \rightarrow \text { potential value of existing housing } \\
\text { decrease } \rightarrow \text { perceived existing house price } \\
\text { decrease } \rightarrow \text { existing house price decrease } \\
\text { (government intention) }\end{array}$ \\
\hline & $\begin{array}{l}\text { - Cost-sale price linkage system: the price of a } \\
\text { house is set by the sum of land costs and } \\
\text { standard building costs, which are decided by the } \\
\text { government }\end{array}$ & $\begin{array}{l}\text { - Cost-sale price linkage system } \rightarrow \text { sales unit price } \\
\text { decrease } \rightarrow \text { expected sales profit decrease } \rightarrow \text { newly } \\
\text { built housing decrease } \rightarrow \text { housing supply decrease }\end{array}$ \\
\hline & \multirow{2}{*}{$\begin{array}{l}\text { - The Bond Bidding System is introduced in } \\
\text { houses that are larger than } 25.7 \text { pyeong when an } \\
\text { applicant/proposer makes a decision (explained } \\
\text { below) }\end{array}$} & $\begin{array}{l}\text { - Cost-sale price linkage system } \rightarrow \text { sales unit price } \\
\text { decrease } \rightarrow \text { actual demand increase }\end{array}$ \\
\hline & & $\begin{array}{l}\text { - Cost-sale price linkage system } \rightarrow \text { expected profit } \\
\text { from newly built house trading increase } \\
\rightarrow \text { investment Demand increase }\end{array}$ \\
\hline \multirow[t]{2}{*}{$\begin{array}{l}\text { New town } \\
\text { development }\end{array}$} & $\begin{array}{l}\text { - Planning to construct } 300,000 \text { houses per year } \\
\text { until } 2010\end{array}$ & \multirow{2}{*}{$\begin{array}{l}\text { - New town development } \rightarrow \text { newly built housing } \\
\text { increase } \rightarrow \text { housing supply increase } \rightarrow \text { perceived } \\
\text { existing house price decrease } \rightarrow \text { existing house } \\
\text { price decrease (government intention) }\end{array}$} \\
\hline & $\begin{array}{l}\text { - For this purpose, the development of a new city } \\
\text { around Seoul and a new town inside Seoul are }\end{array}$ & \\
\hline
\end{tabular}

$\begin{array}{ll}\text { Tax increase } & \begin{array}{l}\text { Holding tax } \\ \text { (property tax) }\end{array}\end{array}$

Transaction tax planned

- By adjusting the standard of imposing ownership tax, the number of properties liable for ownership tax has increased by four times

- Increase of holding tax rate and of the cap of gross holding tax amount

- Impose tax based on the actual market price rather than the declared value which is lower than the actual market price. (burden of transaction tax increases significantly)

- Existing tax rate is less than $30 \%$ irrespective of whether 1 household owns/possesses more than 2 houses; however, for 1 household with more than 2 houses, the new taxation entails a heavy tax rate of more than $50 \%$ being imposed
- Holding tax increase $\rightarrow$ investment demand decrease (government intention)

- Holding tax increase $\rightarrow$ existing housing on sale increase $\rightarrow$ housing supply increase

- Transaction tax increase $\rightarrow$ expected profit from existing house trading decrease $\rightarrow$ investment demand decrease (government intention)

- Transaction tax increase $\rightarrow$ existing housing on sale decrease

Note: A pyeong $=3.058 \mathrm{~m}^{2}$.

Fig. 8, it must be reiterated that such makeshift measures only bring a short-term stabilization of housing prices, which results in adverse effects on the real-estate market over the long-term (Table 3).

As demonstrated by Fig. 8, a controlling mechanism geared toward the establishment of a sales price ceiling might contribute to an incremental increase in actual demand. Furthermore, if this increase continues, lowered interest rates and the expansion of housing funds can accelerate this active demand (i.e., the costsale price linkage system activates the B1-a and B1-b loops seen in Fig. 4). However, if increases in housing prices are due to incongruence between housing supply and demand, actual demand will be reduced (see B2-b in Fig. 6). That said, as sales prices are controlled, house prices will increase to the point at which transaction interest (i.e., expected profit from newly built house trading) is maximized. Under such circumstances, "speculative" investors can control the housing market (see R2 in Fig. 3).

However, from a supplier's perspective, controlling mechanisms might cause less enthusiasm. Indeed, when such a mechanism is in place, it is assumed that developers will not be as eager to participate in the housing market, as they will not be able to benefit from a wide margin between development costs and controlled prices (i.e., they will be unable to control the B1-a loop seen in Fig. 4). Consequently, if developers are not guaranteed a sufficient profit, the supply of small-sized apartments will be reduced, therefore resulting in an increase in the prices of both new and already-built small-sized apartments. Another outcome of such a context is developers opting to concentrate on the development of medium or large-sized apartments, which will presumably yield higher profits. If such a trend continues, the bipolarization of the housing supply market will become even more emphasized.

\section{“New Town” Development}

"New town" development is inextricably linked to housing issues in Korea, as illustrated by the Korean government's prompt decision to build new towns around Seoul in order to stabilize house prices. Although this strategy has been generally accepted as the best way to expand the housing supply in the short term, it has still incited an unending debate. For instance, opposition groups have argued that leaf-frogging development unaccompanied with the construction of basic infrastructures, such as roads and convenience facilities, does not disperse housing demand aimed at the Seoul and Capital Region.

The R2-a loop in Fig. 7 demonstrates that Korean new town development is not linked to the market mechanism. Here, it is assumed that both floating funds and implicit speculative demand still exist. Because future homeowners and investors will gener- 
ally want to enjoy the realization of the expected transaction interest, it becomes essential that the government construct new towns with greater housing attractiveness. As a result, new town developments will inevitably provoke excessive competition for brand-new housing with high attractiveness. Furthermore, if the government appropriates a higher unit sales price in new town developments, it seems inevitable that there will be a price transfer toward regions with more attractive housing (see R1 in Fig. 3).

\section{Tax Increases}

One of the 831 Countermeasures' most publicized aspects are the tax increases for real-estate purchases, capital gains, and transactions. The government not only predicted that increased realestate taxes (e.g., holding and transfer taxes) would reduce opportunities to profit from home ownership, they also expected that these taxes would oppress speculative demand (MOFE 2005). However, if such a trend continues, because holding a house entails a tax burden for the housing holder, more houses might continue to be put on the market (i.e., an increase in existing housing on sale) over the long-term, potentially resulting in a drop in house prices (i.e., the government's intention to control the R2-b loop's function seen in Fig. 7).

However, it is crucial that this so-called "benevolent" housing policy does not, in fact, differentiate the supply-housing market from the demand-housing market. From a supplier's perspective, increased holding taxation will increase the housing supply in regions with relatively low housing attractiveness. However, in regions with relatively high housing attractiveness such as Kangnam, where house prices have rapidly increased, the tax burden derived from this increased taxation will discourage homeowners in Kangnam to put their houses on the market. This, of course, will result in a decrease in sales stocks. As well, because this tax policy imposes a high tax rate on multiple homeowners, this decrease in housing supply will be heightened.

From a demander's perspective, on the other hand, speculative and total demand will be reduced because hefty transaction taxes will inevitably reduce the expected transaction difference. However, in the case of regions with a relatively high housing attractiveness, potential demand will be maintained, even as housing demand decreases; this is due to the scarcity value of the regional attributes and high housing attractiveness. Consequently, as the government intended, increased taxation did lower housing prices in regions of relatively low housing attractiveness due to the increase in supply and decrease in demand. However, in the case of regions with relatively high housing attractiveness, which are the main target of the 831 Countermeasures, the impact of increased taxation has not been so great. This is because the decrease in supply (i.e., existing housing on sale) exceeds the decrease in demand.

Fig. 9 shows house price volatility in the capital region and all of Korea. This national data are presented by price index, compared with house prices in January 2006 (i.e., the Price index in January $2006=100$ ). Similarly, Fig. 10 illustrates the volatility of housing transactions 5 months after the government announced the 831 Countermeasures. As previously noted, over the longterm, there was a continuous increase in house prices and little volatility in housing transactions. On the contrary, in the capital region, which maintained high housing attractiveness and a housing demand increase, there was a decrease in existing housing on sale because of the holding tax burden. Therefore, it can be observed that the policy results in potential increases in housing prices due to the supply and demand functions.
House Price Index in Korea

$(06.1=100)$

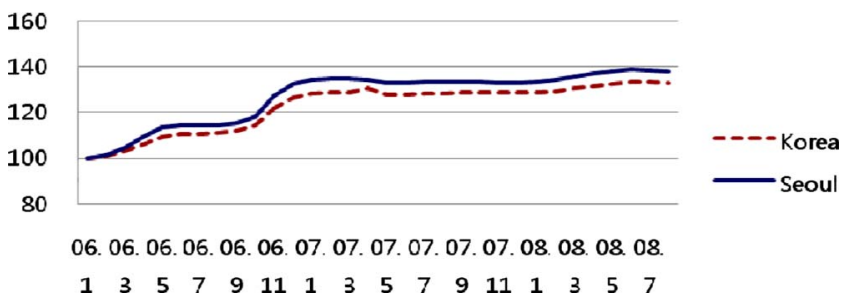

Fig. 9. Korean house price index

\section{Analyzing 831 Countermeasures: Case of Kangnam}

While an examination of the theoretical basis and positive and negative aspects of the 831 Countermeasures certainly clarifies the aims of the government policy, the practical applicability of such a policy must also be rigorously examined. As well, it must be taken into account that the housing market is an organic and complex mechanism driven by a series of feedback loops, and especially for the purpose of reliable market forecasting, the loops that are most prevalent in the total system must be identified. To this end, this research uses system dynamics to simulate the 831 Countermeasures for Kangnam, a neighborhood in the south of Seoul, which has maintained the highest level of housing attractiveness for the past several decades and has thus been blamed for driving up Korean housing prices.

Fig. 8 illustrates the 831 Countermeasures' basic policy mechanism for Kangnam. First, the purpose of the increased transaction taxation was to cut expected profit from existing house trading, which, in turn, was meant to decrease investment demand and also reduce the existing housing on sale because high expected trading profits are due to continually increasing housing prices in Kangnam. Then, the increased transfer taxation and holding taxation were meant to decrease housing demand, particularly in Kangnam, as Kangnam's housing attractiveness and scarcity value will continue to be maintained and most likely increase, and imputed demand will continue to be maintained provided that trading profits exceed the transfer income tax.

As a result of Kangnam's maintained housing attractiveness/ scarcity, diminished supply and demand will reduce the total volume of housing transactions, thus leading to an increase in the time horizon for existing house price. This implies that the widened gap between perceived existing house price and existing house price will amplify the effect of the R2-b loop. In other words, a certain amount of time must pass so that perceived changes in housing demand may be reflected in housing prices; however, due to the contraction of housing transactions, this will lead to an amplification of the change in investment demand.

\section{Housing Transaction (Area, $1000 \mathrm{~m}^{2}$ )}

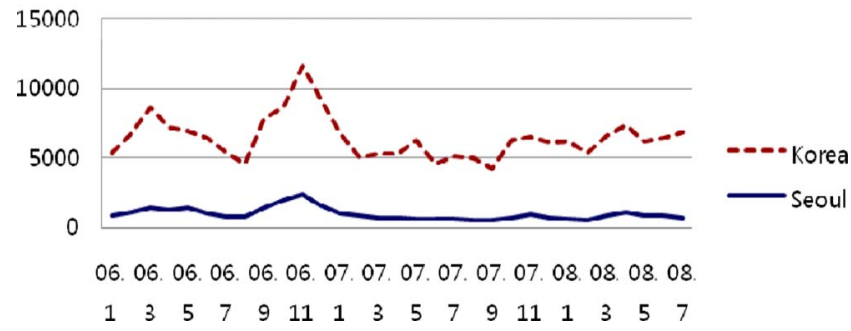

Fig. 10. Korean housing transactions 
Under such circumstances, and owing to sales price increases in surrounding new town areas, it is quite possible that Kangnam's potential value will continue to soar. Consequently, the R2-b loop would be activated, resulting in increasing investment demand generating higher perceived existing house prices in Kangnam. The aforementioned low volume of transactions would greatly amplify the effect of the R2-b loop, thus increasing the probability that Kangnam house prices will be boosted (under the 831 Countermeasures).

In fact, after the Korean government proposed the 831 Countermeasures, the price gap between Kangnam and other regions widened from August 2005 to February 2006 (The KB Bank 2006). Fortunately for the upper class in Kangnam, the limited sales volume of housing was virtually immune to the taxation policy implemented by the government. Ultimately, these trends have resulted in the deepening of housing bipolarization and class disparities already evident in Korean society.

\section{Summary and Conclusions}

Using a qualitative system dynamics model, this study has attempted to elucidate and analyze the impact of the 831 Countermeasures on key components of Korea's housing market. Causal loop analyses of the housing sector have indicated that the housing market is run by house prices that are self-regulated by supply and demand, and particularly under the influence of balancing loops such as the supply controlling loops (B1-a, B1-b, B1-c, B1-d) and demand controlling loops (B2-a, B2-b). Also, when reinforcing loops related to house price and investment demand are self-regulated in the affirmative directions, the housing market will become stable with active housing transactions. Conversely, if reinforcing loops are caught in a vicious cycle, the government can intervene in the housing market by stimulating the reinforcing loops' operation to change direction. In this respect, the implications of this policy, as obtained from this research, are summarized as follows.

First, the cost-sale price linkage system can strengthen the activation of the balancing loops (B2-b) related to housing supply. Nevertheless, the vicious cycle of R1 loops connected with housing price volatility could grow worse. Similarly, new town development could also deepen the negative side effects of the R1 loops. In fact, it will take some time before that particular policy, new town development, can have a positive influence on the balancing loops linked with housing supply. Moreover, when the government intervenes in the housing market to regulate investment demands by increasing taxes, they should wait for balancing loops to dominate the market, even though price and speculative demand related to the reinforcing loop (R1) will be increased in the short term.

Using system dynamics modeling to perform qualitative analysis, this study also highlights the need to devise policy alternatives that are based on regional disparities in housing attractiveness and housing prices. These factors must not be dismissed. For this purpose, housing planning should prioritize upgrading the housing attractiveness of a target area, not the housing volume of that area. Finally, new town projects should not be implemented solely for the purpose of stabilizing house prices, but also to provide a good dwelling environment for residents. Indeed, increasing housing volume cannot be the fundamental solution to such complex problems, for such an approach will only lead to the gradual deterioration of dwelling environments.

\section{Acknowledgments}

This research was supported by a grant (Grant No. 05CIT-D0501) from Construction Technology Innovation Program funded by Ministry of Land, Transport and Maritime Affairs of the Korean Government. This research supported by a grant (Grant No. 07UrbanRenaissanceA03) from High-Tech Urban Development Program funded by the Ministry of Construction and Transportation of the Korean Government.

\section{References}

Ahmad, S., and Simonovic, S. (2000). "System dynamics modeling of reservoir operations for flood management." J. Comput. Civ. Eng., 14(3), 190-191.

Cho, D., and Ma, S. (2006). "Dynamic relationship between housing values and interest rates in the Korean housing market." J. Real Estate Finance Econ., 32(2), 169-184.

Englund, P., Quigley, J. M., and Redfearn, C. L. (1999). "The choice of methodology for computing housing price indexes: Comparison of temporal aggregation and sample definition." J. Real Estate Finance Econ., 19(2), 91-112.

Guirguis, H. S., Giannikos, C. I., and Anderson, R. I. (2005). "The US housing market: Asset pricing forecasts using time varying coefficients." J. Real Estate Finance Econ., 30(1), 33-53.

Hur, J. W. (1991). "An empirical analysis of the determination of house price inflation rates." J. Korea Planners Association, 26(2), 141-151.

Hur, J. W. (1993). "An empirical analysis on the economic effects of the removal of price control for new housing: With special reference to housing price." J. Korea Planners Association, 28(3), 85-101.

Hur, J. W., and Ha, S. G. (1990). "The study of interconnection between new house market and old house market." House banking, Vol. 125, Korea, 11-12.

The KB Bank. (2006). The present condition of house price in the country.

Kim, C. H., and Kim, K. H. (1998). "Political economy of government policy on real-estate in Korea: Torn between de-regulation and antispeculation." CFE papers on Korean economy, The Korea Center for Free Enterprise, Seoul.

Kim, H. A., and Lee, S. W. (2005). Effect that real-estate countermeasure gets in the construction industry, Construction and Economy Research Institute of Korea, Nonhyun-dong, Korea, 26-47.

Kim, K. H. (2004). "Housing and the Korean economy." J. Hous. Econ., $13,321-341$.

Ministry of Finance and Economy of the Korean Government (MOFE). (2005). Real-estate innovation system for people residing stability and speculation in real-estate constraint (8-31 Countermeasures), Korea.

Park, S., Bahng, D., and Park, Y. (2008). "Price run-up in housing markets, access to bank lending and house prices in Korea." The journal of real estate finance and economics, Springer, Berlin.

Sterman, J. (2000). Business dynamics: System thinking and modeling for a complex world, McGraw-Hill, New York, 191-232.

Zietz, J., Zietz, E. N., and Andmans, G. S. (2008). "Determinants of house price: A quantile regression approach." J. Real Estate Finance Econ., 37(4), 317-333. 